\title{
Y-12 GROUNDWATER PROTECTION PROGRAM GROUNDWATER MONITORING DATA COMPENDIUM REVISION 3
}

Y-12 NATIONAL
SECURITY
COMPLEX 


\section{DISCLAIMER}

This report was prepared as an account of work sponsored by an agency of the United States Government. Neither the United States Government nor any agency thereof, nor any of their employees, makes any warranty, express or implied, or assumes any legal liability or responsibility for the accuracy, completeness, or usefulness of any information, apparatus, product, or process disclosed, or represents that its use would not infringe privately owned rights. Reference herein to any specific commercial product, process, or service by trade name, trademark, manufacturer, or otherwise, does not necessarily constitute or imply its endorsement, recommendation, or favoring by the United States Government or any agency thereof. The views and opinions of authors expressed herein do not necessarily state or reflect those of the United States Government or any agency thereof. 
Y/TS-1983/R3/V1

\title{
Y-12 GROUNDWATER PROTECTION PROGRAM GROUNDWATER MONITORING DATA COMPENDIUM REVISION 3
}

December 2009

\author{
Prepared by \\ Elvado Environmental LLC \\ Under Subcontract No. 4300068789
}

for the

Environmental Compliance Department

Environmental, Safety, and Health Division

Y-12 National Security Complex

Oak Ridge, Tennessee 37831

\author{
Managed by \\ Babcock \& Wilcox Technical Services Y-12, LLC \\ for the U.S. DEPARTMENT OF ENERGY \\ Under Contract No. DE-AC05-00OR22800
}




\section{CONTENTS}

$\underline{\text { Section }}$

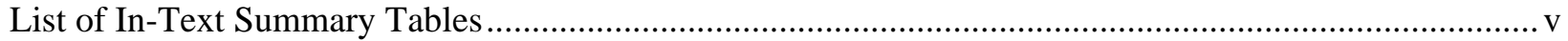

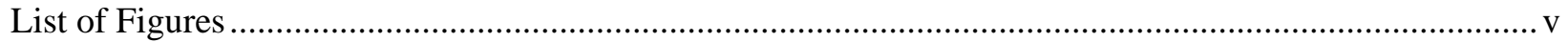

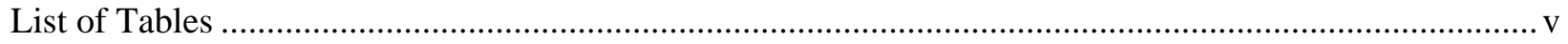

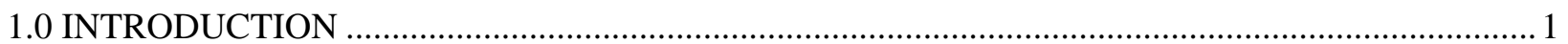

1.1 SCOPE

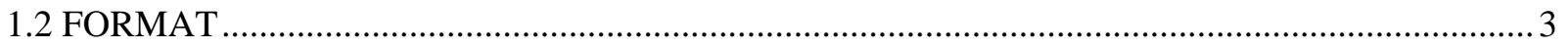

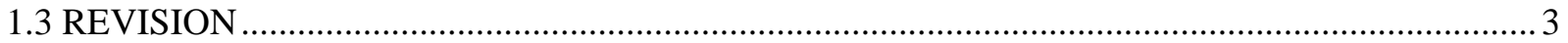

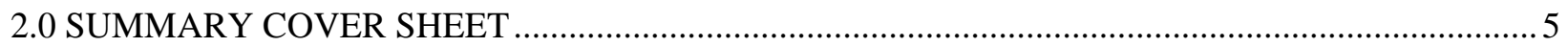

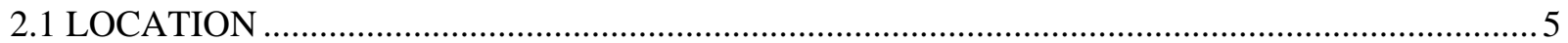

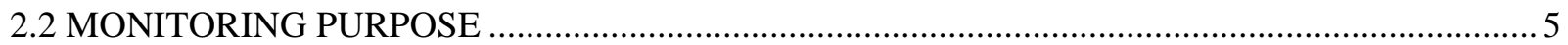

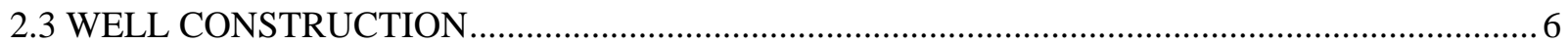

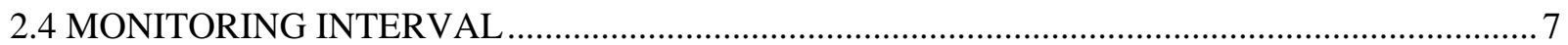

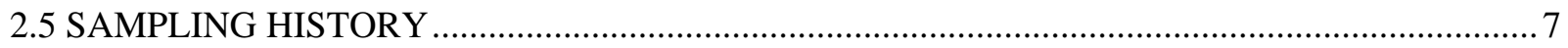

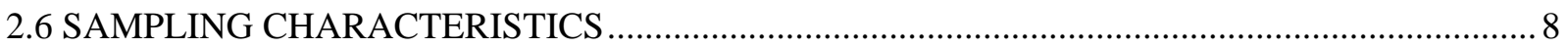

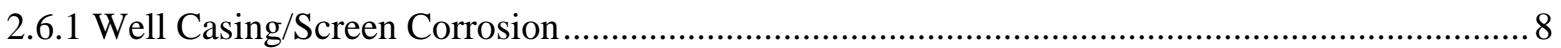

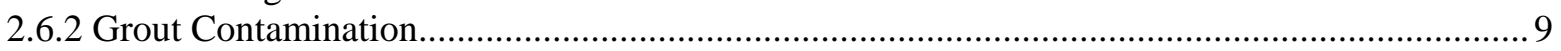

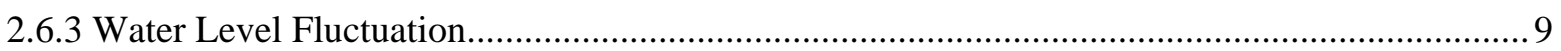

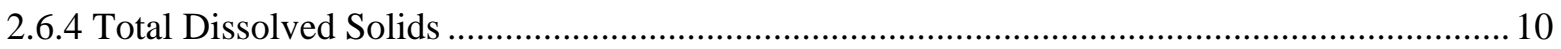

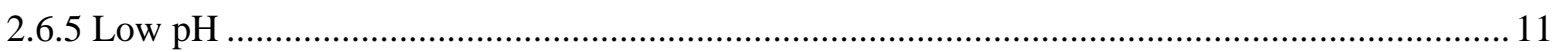

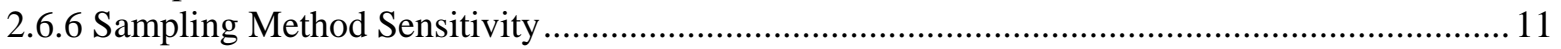

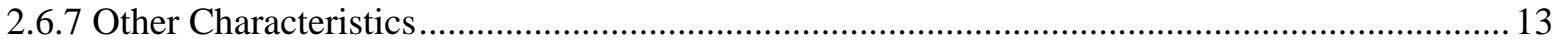

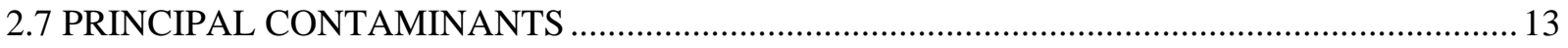

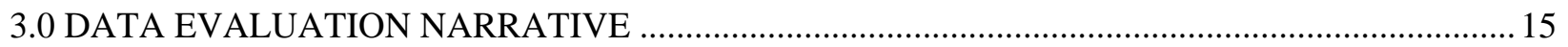

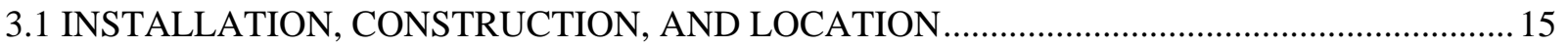

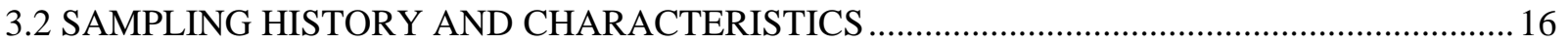

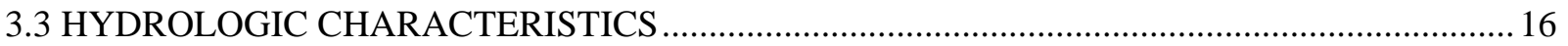

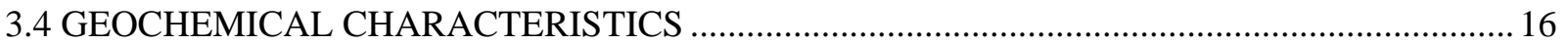

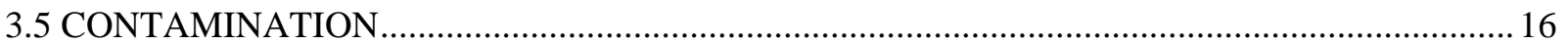

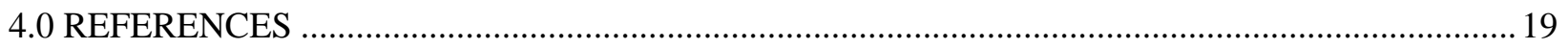

APPENDICES:

A FIGURES

B TABLES

ATTACHMENT: COMPACT DISK, containing:

Vol2 to GW-199_r3.pdf

Vol3 to GW-699_r3.pdf

Vol4 to GW-960_r3.pdf

Vol5 SW/Springs_r3.pdf 


\section{List of In-Text Summary Tables}

$\underline{\text { Table }}$

$\underline{\text { Page }}$

1. Wells with suspected corrosion of the riser casing/well screen ..................................................... 8

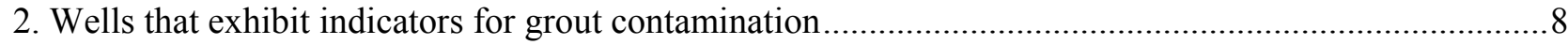

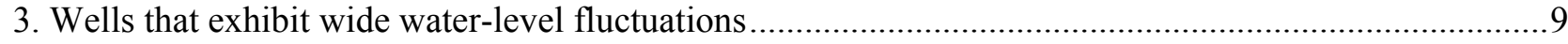

4. Wells that yield groundwater with unusually high or unusually low TDS .......................................

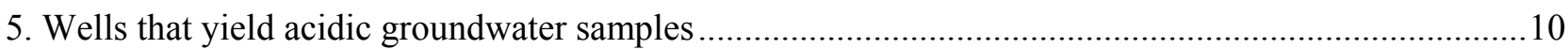

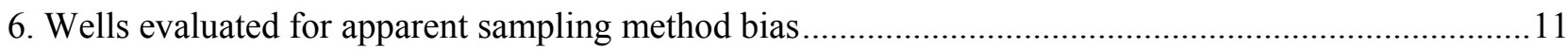

7. Principal contaminants and corresponding screening levels ..........................................................12

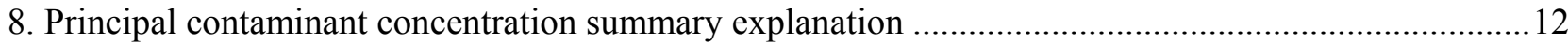

$\underline{\text { Figure }}$

\section{List of Figures}

A.1. Hydrogeologic regimes at the Y-12 National Security Complex ............................................... A-1

A.2. Bedrock geology and topography in the vicinity of the Y-12 National Security Complex ............ A-2

$\underline{\text { Table }}$

\section{List of Tables}

$\underline{\text { Page }}$

B.1. Index of monitoring wells included in Volume 2 of the Y-12 GWPP compendium........................

B.2. Index of monitoring wells included in Volume 3 of the Y-12 GWPP compendium........................

B.3. Index of monitoring wells included in Volume 4 of the Y-12 GWPP compendium..........................3

B.4. Index of sampling stations included in Volume 5 of the Y-12 GWPP compendium....................... 


\subsection{INTRODUCTION}

This document is a compendium of water quality and hydrologic characterization data obtained from the network of groundwater monitoring wells and selected surface water sampling stations (including springs and building sumps) at the U.S. Department of Energy (DOE) Y-12 National Security Complex (Y-12) in Oak Ridge, Tennessee that have been sampled between January 2003 and December 2008. The primary objectives of this document, hereafter referenced as the Y-12 Groundwater Protection Program (GWPP) Compendium, are to:

- Serve as a single-source reference for monitoring data that meet the requirements of the Y-12 GWPP, as defined in the Y-12 GWPP Management Plan (Babcock \& Wilcox Technical Services Y-12 LLC [B\&W Y-12] 2009a);

- Maintain a detailed analysis and evaluation of the monitoring data for each applicable well, spring, and surface water sampling station, with a focus on results for the primary inorganic, organic, and radiological contaminants in groundwater and surface water at Y-12; and

- Ensure retention of "institutional knowledge" obtained over the long-term ( $>20$-year) history of groundwater and surface water monitoring at Y-12 and the related sources of groundwater and surface water contamination.

To achieve these goals, the Y-12 GWPP Compendium brings together salient hydrologic, geologic, geochemical, water-quality, and environmental compliance information that is otherwise disseminated throughout numerous technical documents and reports prepared in support of completed and ongoing environmental contamination assessment, remediation, and monitoring activities performed at Y-12.

The following subsections provide background information regarding the overall scope and format of the Y-12 GWPP Compendium and the planned approach for distribution and revision (i.e., administration) of this document. Figures and tables (excluding data summary tables presented with the text) referenced in this introductory volume are provided in Appendix A and Appendix B, respectively.

\subsection{SCOPE}

This Y-12 GWPP Compendium includes groundwater monitoring wells granted "active" status in accordance with the Y-12 GWPP Monitoring Optimization Plan (MOP) (B\&W Y12 2009b), including wells for which the monitoring status has changed to "inactive" at some time following the sampling events described in this document. The MOP grants active status to any well that meets one or more of the following criteria: (1) the well is designated for monitoring in compliance with applicable state and/or federal regulations; (2) the well meets requirements of DOE Order 450.1A surveillance monitoring; (3) the well is designated for hydrologic monitoring (e.g., water level elevations); and (4) the well is considered suitable for objectives of the Y-12 GWPP. The Y-12 GWPP Compendium provides the following information for wells granted active status under the MOP:

- A summary of pertinent well-construction information (e.g., total depth);

- An overview of the groundwater sampling history for the well and a discussion of distinguishing sampling characteristics (e.g., unusually high or low total dissolved solids [TDS] concentration); 
- A discussion of the hydrologic characteristics for the well, based primarily on presampling depthto-water measurements/groundwater elevations, along with a summary of available results for hydrologic tests (e.g., hydraulic conductivity tests);

- A discussion of the geochemical characteristics of the groundwater in the well based on available analytical results for primary anions and cations, including a discussion of results showing unusually high or low ion concentrations, or other similarly distinctive geochemical characteristics;

- A detailed narrative evaluation of the available analytical results for the well, supported by timeseries plots and data summary tables, based on monitoring results that meet the requirements of the Y-12 GWPP for the primary groundwater contaminants at Y-12: nitrate, uranium, volatile organic compounds (VOCs), and radioactivity (gross alpha activity and gross beta activity); and

- A list of plans, documents, and technical reports cited for more detailed information.

The Y-12 GWPP Compendium presents a Brief of the above-listed information for each well, which includes a Summary Cover Sheet and corresponding Data Evaluation Narrative, each of which is divided into the following sections: (1) Installation, Construction, and Location; (2) Sampling History and Characteristics; (3) Hydrologic Characteristics; (4) Geochemical Characteristics; (5) Contamination, with subsections for nitrate, uranium, VOCs, gross alpha activity, gross beta activity, and other contaminants (if any); and (6) References. Section 2 of this introductory report provides a detailed explanation of the data presented in the Summary Cover Sheet for each well and Section 3 outlines the types of information provided in the corresponding Data Evaluation Narrative.

This Y-12 GWPP Compendium also includes a number of natural springs and surface water sampling locations in the drainage basins associated with Y-12, including sampling locations that are outside the boundary of the DOE Oak Ridge Reservation. The Y-12 GWPP uses these sampling locations for the purposes of Exit Pathway/Perimeter monitoring in accordance with the requirements of DOE Order 450.1. Several of these sampling locations also meet the requirements of other monitoring programs and organizations at Y-12, including National Pollution Discharge Elimination System (NPDES) monitoring performed by the Y-12 Surface Water Program. Based only on selected sampling/analytical results that meet DOE Order monitoring requirements, the Y-12 GWPP Compendium provides the following information for each applicable spring and surface water sampling station:

- The general location of the spring or surface water sampling station, including the Y-12 grid coordinates;

- The purpose for monitoring the spring or surface water sampling station (e.g., DOE Order monitoring) and the sampling history;

- A discussion of the geochemical characteristics of the samples from the spring or surface water stations, based on available analytical results for primary anions and cations;

- A summary of water-quality conditions at each spring or surface water sampling station, based on sampling/analytical results for the following surface water contaminants at Y-12: nitrate, uranium, VOCs, radioactivity (gross alpha activity and gross beta activity), and mercury (selected locations only); and

- A list of plans, documents, and technical reports cited for more detailed information. 
As with the wells, the Y-12 GWPP Compendium presents a Brief of the above-listed information for each spring and surface water station in a Summary Cover Sheet and corresponding Data Evaluation Narrative, each formatted with the following sections: (1) Location; (2) Sampling History; (2) Geochemical Characteristics; (4) Principal Contamination, with subsections for nitrate, uranium, VOCs, gross alpha activity, gross beta activity, and other contaminants, such as mercury; and (5) References. Much of the information included in the Summary Cover Sheet and Data Evaluation Narrative for each spring and surface water sampling station is self-explanatory or is otherwise addressed by the descriptions provided Section 2 and Section 3 of this introductory volume.

The Y-12 GWPP Compendium includes only the applicable wells (i.e., those granted "active" status under the MOP) and surface water monitoring stations (including springs) that have been used for groundwater or surface water quality sampling since January 2003. Nevertheless, as described in the following sections, the compendium format accommodates the addition of other sampling locations that may be included in ongoing groundwater and surface water monitoring activities. Additionally, the compendium maintains information regarding wells that were formerly granted active status, but whose monitoring status has changed to inactive (e.g., wells plugged and abandoned to make room for buildings). With this approach, the Y-12 GWPP Compendium encompasses nearly all of the wells at Y-12 that are granted "active" status under the MOP and are selected for water quality monitoring by the Y-12 GWPP.

\subsection{FORMAT}

To facilitate use as a reference manual, the Y-12 GWPP Compendium is presented in a "handbook" format. This format is intended for wide distribution and consists of a hardcopy of this introductory report along with a compact disk containing four portable document format (PDF) files (Volumes 2, 3, 4, and 5) that have the most up-to-date Brief for each applicable well, spring, and surface water sampling station (see Attachment). The PDF files are fully searchable with compatible software (e.g., Adobe Acrobat $\left.^{\mathrm{TM}}\right)$. The entire Y-12 GWPP Compendium is divided into five separate volumes in the manner of an encyclopedia, with this introduction being Volume 1 and the Brief for each applicable sampling location presented in Volume 2 (Table B.1), Volume 3 (Table B.2), Volume 4 (Table B.3), and Volume 5 (Table B.4). The referenced index tables identify the wells included in Volume 2 (wells $1090-$ GW-199), Volume 3 (wells GW-200 - GW-699), and Volume 4 (wells GW-700 - GW-999) and the springs, sumps, and surface water sampling stations included in Volume 5.

\subsection{REVISION}

The Y-12 GWPP Compendium will be revised (updated) annually or at an alternative frequency specified by the Y-12 GWPP Manager. The revisions will primarily involve: (1) updating the information presented in this introductory volume, particularly the above-referenced index tables and the data summary tables presented in Section 2; (2) updating the information presented in the Summary Cover Sheet and Data Evaluation Narrative for each applicable well, spring, or surface water station to incorporate the results of on-going groundwater and surface water quality monitoring activities; and/or (3) adding the Summary Cover Sheet and Data Evaluation Narrative for applicable wells, springs, or surface water stations not previously included in the Y-12 GWPP Compendium. The current revision of this document includes new Briefs for monitoring locations that were sampled at least once during CY 2007 and/or CY 2008 (the previous revision updated all locations with monitoring results through CY 2006); none of the existing Briefs were updated to reflect the sampling results during this time period. 
Revised versions of this "handbook" format will include an updated hardcopy of the introductory report (this document) along with a compact disk that contains new PDF files with the updated Brief for each applicable well, spring, and surface water sampling station. 


\subsection{SUMMARY COVER SHEET}

The Summary Cover Sheet for each applicable sampling location included in the Y-12 GWPP Compendium serves as a quick reference for general information about the well, spring, or surface water sampling station. This section provides background information regarding the contents of the Summary Cover Sheet for each well, which also addresses the contents of the Summary Cover Sheet for each spring and surface water station.

The Summary Cover Sheet for each applicable monitoring well included in the Y-12 GWPP Compendium, as detailed below, is divided into the following sections: (1) Location; (2) Monitoring Purpose; (3) Well Construction; (4) Monitored Interval; (5) Sampling History; (6) Sampling Characteristics, and (7) Principal Contaminants. Information is provided on the Summary Cover Sheet unless it is not available (NA) or is not applicable (“.”).

\subsection{LOCATION}

This section of the Summary Cover Sheet provides general location information for the well, including the hydrogeologic regime in which the well is located and the site (Functional Area) with which the well is affiliated. Often, the affiliated site is a source of contamination in the groundwater at the well. The Y-12 GWPP recognizes three hydrogeologic regimes at Y-12 (Figure A.1): (1) the Bear Creek Hydrogeologic Regime (referenced as the Bear Creek Regime), which encompasses a section of Bear Creek Valley (BCV) west of Y-12; (2) the Upper East Fork Poplar Creek Hydrogeologic Regime (referenced as the East Fork Regime), which encompasses the section of BCV that includes the bulk of the process and support buildings that comprise Y-12; and (3) the Chestnut Ridge Hydrogeologic Regime (referenced as the Chestnut Ridge Regime), which encompasses a section of Chestnut Ridge directly south of Y-12.

\subsection{MONITORING PURPOSE}

This section of the Summary Cover Sheet identifies the applicable groundwater monitoring program under which samples were collected during the most recent year. Although collected for a variety of monitoring purposes, all of the data presented in this document meet U.S. Department of Energy (DOE) Order 540.1 monitoring requirements. Ongoing groundwater quality monitoring activities in the hydrogeologic regimes at Y-12 are implemented in accordance with the following programs:

- Resource Conservation and Recovery Act (RCRA) post-closure groundwater quality monitoring, which includes RCRA post-closure detection monitoring and RCRA post-closure corrective action effectiveness monitoring. The former is performed at closed hazardous waste disposal units (HWDUs) that have not released hazardous waste and/or hazardous waste constituents to the groundwater system, and the latter is performed at HWDUs which have released hazardous waste and/or hazardous waste constituents. The requirements for these RCRA monitoring programs are defined in the respective RCRA post-closure permit issued by the Tennessee Department of Environment and Conservation (TDEC) for each hydrogeologic regime and the applicable TDEC regulations governing groundwater monitoring at HWDUs. 
- Comprehensive Environmental Response, Compensation, and Liability Act (CERCLA) groundwater quality monitoring, which includes: (1) CERCLA baseline monitoring to evaluate preremediation groundwater quality; (2) monitoring performed in accordance with the applicable CERCLA record of decision (ROD) and or related decision documents pending final approval of the ROD; and (3) monitoring performed at the Environmental Management Waste Management Facility, which is an active CERCLA-regulated waste disposal site located in the Bear Creek Regime west of Y-12.

- Groundwater quality monitoring performed at several operating and closed non-hazardous waste landfills located south of Y-12 in the Chestnut Ridge Regime. Monitoring at each site is performed in accordance with the operating permit/post-closure plan issued and approved by the TDEC and the TDEC regulations governing groundwater monitoring at non-hazardous solid waste disposal facilities.

- Groundwater quality monitoring performed in each hydrogeologic regime in compliance the requirements of DOE Order 450.1, which mandates monitoring in areas at Y-12 that: (1) are known or suspected sources of groundwater contamination and (2) where contaminants from DOE operations at Y-12 may exit areas under DOE administrative control.

In addition to groundwater quality monitoring, respective networks of groundwater monitoring wells in the Bear Creek Regime, East Fork Regime, and Chestnut Ridge Regime are used for hydrologic monitoring (i.e., are used to determine contemporaneous, regime-wide groundwater surface elevations).

\subsection{WELL CONSTRUCTION}

This section of the Summary Cover Sheet provides selected information regarding the construction of the monitoring well, as reported in: Updated Subsurface Data Base for Bear Creek Valley, Chestnut Ridge, and Parts of Bethel Valley on the U.S. Department of Energy Oak Ridge Reservation (BWXT 2003), hereafter referenced as the Y-12 Subsurface Database. Many of the monitoring wells are completed in pairs or clusters, and the Summary Cover Sheet notes all clustered wells. For most wells, the total depth of the well (Tag Depth) is in reference to the top of the well casing, whereas other downhole measurements may be in reference to a designated measuring point marked on the top of the Well Wizard $^{\mathrm{TM}}$ (TOWW) (a dedicated gas-driven bladder pump) in the well. The type of dedicated sampling equipment (to be used only for the specified well) installed in the well is noted in this section; most monitoring wells have a Well Wizard ${ }^{\mathrm{TM}}$ bladder pump. A few wells are equipped with Westbay ${ }^{\mathrm{TM}}$ multiport sampling systems that enable collection of representative samples from several discreet depth intervals. Additionally, the following acronyms and abbreviations are used for well casing materials and well screen types (if applicable):

$\begin{array}{lll}\text { PVC40 } & - & \text { polyvinyl chloride, schedule } 40 \\ \text { PVC/SL } & - & \text { PVC/slotted } \\ \text { PPK } & - & \text { pre-packed screen } \\ \text { SF25/SJ55 } & - & \text { steel; American Petroleum Institute Grade } \\ \text { STL } & - & \text { carbon steel } \\ \text { SS } & - & \text { stainless steel } \\ \text { SS304 } & - & \text { stainless steel type } 304 \\ \text { SS/SW } & - & \text { stainless steel, spiral wound } \\ \text { slot size } & - & \text { size of screen openings, in inches (e.g., 0.01) }\end{array}$




\subsection{MONITORING INTERVAL}

This section of the Summary Cover Sheet provides selected information regarding the monitored interval for the well, as reported in the Y-12 Subsurface Database. All the monitoring wells at Y-12 that are granted active status under the Y-12 GWPP are completed with manufactured well screens or open hole monitored intervals, respectively referenced as "Screened" and "Open Hole" on the Summary Cover Sheet. Also provided are the depths to the top, bottom, and midpoint of the monitored interval, as measured in $\mathrm{ft}$ below ground surface (bgs), and the corresponding elevations in $\mathrm{ft}$ above mean sea level (msl).

As noted in the Section 2.3, most of the monitoring wells granted active status under the Y-12 GWPP are equipped with a dedicated sampling pump. Therefore, this section of the Summary Cover Sheet for these wells shows the depth to the pump intake, which provides information regarding its relative location within the monitored interval for the well.

This section of the Summary Cover Sheet also identifies the geologic formation from which the monitoring well yields groundwater. The primary geologic formations in the vicinity of Y-12 are (listed in order from oldest to youngest): the Rome Formation, which forms Pine Ridge north of Y-12; the Conasauga Group formations (Pumpkin Valley Shale, Rutledge Limestone, Rogersville Shale, Mayville Limestone, Nolichucky Shale, and Maynardville Limestone), which underlie Bear Creek Valley (BCV) and the southern flank of Pine Ridge; and the Knox Group formations (Copper Ridge Dolomite, Chepultepec Dolomite, Longview Dolomite, Kingsport Formation, and Mascot Dolomite), which form Chestnut Ridge south of Y-12 (Figure A.2).

The geologic formations in the vicinity of Y-12 comprise two hydrogeologic units: the aquifer, consisting of the Maynardville Limestone (upper Conasauga Group) and Knox Group formations; and the aquitard, consisting of the remaining Conasauga Group formations and the Rome Formation. Fractures provide the principal groundwater flowpaths in both units, and dissolution of carbonates in the aquifer has enlarged fractures and produced solution cavities and conduits that greatly enhance its hydraulic conductivity relative to the aquitard. Flow in each unit decreases with depth, and flow through the porous rock matrix is minimal in both units. Also, the bulk of the groundwater flow in each unit occurs within a highly permeable hydrogeologic zone, referenced as the "Water Table" in this section of the Summary Cover Sheet, located near the interface between bedrock and weathered bedrock/residuum. In the aquifer, the water table interval represents an extensively interconnected network of solution conduits and cavities (shallow karst network). Wells completed below the water table interval are noted as monitoring a "Bedrock" hydrogeologic zone.

\subsection{SAMPLING HISTORY}

This section of the Summary Cover Sheet presents the groundwater sampling history for the well, including the total number of sampling events with the initial and most recent sampling dates of the current revision (see Section 1.3). The sampling history includes sampling events performed by the Y-12 GWPP (January 1986 - present), samples collected by various programs managed by Bechtel Jacobs Company LLC (October 1996 - present), and selected sampling results obtained for CERCLA remedial investigations in the Bear Creek and East Fork Regimes (1997 - 1998). The sampling history also shows the number of samples that have been obtained with the two groundwater sampling methods that have been employed by the Y-12 GWPP and other organizations: a low-flow minimal drawdown sampling method (hereafter referenced as low-flow sampling) and a "conventional" sampling method. The lowflow sampling method, which is intended to obtain representative groundwater samples that do not 
include stagnant water in the well casing, involves pumping groundwater from the well at a flow rate that is low enough ( $<300$ milliliters per minute) to minimize drawdown of the water level in the well $(<0.1 \mathrm{feet}$ [ft] per quarter-hour) and collecting groundwater samples when regular measurements of $\mathrm{pH}$, conductivity, temperature, oxidation-reduction potential, and dissolved oxygen show minimal variation over four consecutive readings. In contrast, the conventional sampling method involves collecting groundwater samples immediately after purging at least three well volumes of groundwater from the well (if the well does not purge dry) at a much higher pumping rate (1.0 to 1.8 gallons per minute).

\subsection{SAMPLING CHARACTERISTICS}

Most of the groundwater monitoring wells at Y-12 that are granted active status under the Y-12 GWPP monitor uncontaminated groundwater, exhibit similar hydrologic characteristics (e.g., seasonal water level fluctuations), and yield groundwater samples with similar geochemical characteristics. As described in the following paragraphs, analytical results some of the wells granted active status are conspicuous with regard to: (1) elevated chromium and/or nickel concentrations believed to be artifacts related to the corrosion of the stainless steel riser casing and/or well screen; (2) unusual geochemical characteristics indicative of residual contamination from the cement grout emplaced during well installation/construction; (3) analytical results that appear to reflect bias from the groundwater sampling method; (4) large temporal fluctuations in groundwater elevations; (5) unusually high or low TDS; (6) acidic $(\mathrm{pH}<5.5)$ groundwater, and (7) some other distinguishing geochemical characteristic.

\subsubsection{Well Casing/Screen Corrosion}

This characteristic applies to wells that yield groundwater samples containing unusually high concentrations of chromium and/or nickel that are most likely attributable to chemical and/or microbiologically induced corrosion of the stainless steel well casing/screen. Elevated concentrations of these metals reported for samples from the following wells are believed to be artifacts of corrosion of the riser casing/well screen.

Table 1. Wells with suspected corrosion of the riser casing/well screen

\begin{tabular}{|c|cc|c|}
\hline $\begin{array}{c}\text { BEAR CREEK } \\
\text { REGIME }\end{array}$ & \multicolumn{2}{|c|}{ EAST FORK } & CHESTNUT RIDGE \\
REGIME & GW-508 & GW-292 \\
\hline GW-056 & 55-1A & GW-302 \\
GW-715 & 56-1A & GW-696 & GW-305 \\
& 59-1A & GW-760 & GW-339 \\
& 59-1B & GW-776 & \\
\hline & GW-190 & GW-783 & GW-792 \\
\hline
\end{tabular}

These wells are suitable for monitoring contaminants other that nickel and chromium (e.g., organics); however, redevelopment of these wells prior to sampling is recommended to ensure collection of the most representative groundwater samples. 


\subsubsection{Grout Contamination}

This characteristic applies to wells that yield groundwater samples with unusual geochemical characteristics, including strongly basic $\mathrm{pH}(>9)$ and elevated concentrations of potassium $(>10 \mathrm{mg} / \mathrm{L})$, that are believed to be the result of localized contamination from cement grout circulated into the surrounding bedrock during installation and construction of the well. This grout contamination may occur several years after well installation, especially in karst areas where additional grout (significantly more than the calculated annular space) may have been used to install the well casing. Such geochemical characteristics are indicated by the monitoring results obtained from the wells listed below in Table 2 .

Table 2. Wells that exhibit indicators for grout contamination

\begin{tabular}{|c|c|c|}
\hline $\begin{array}{c}\text { BEAR CREEK } \\
\text { REGIME }\end{array}$ & $\begin{array}{c}\text { EAST FORK } \\
\text { REGIME }\end{array}$ & $\begin{array}{c}\text { CHESTNUT RIDGE } \\
\text { REGIME }\end{array}$ \\
\hline None in the Compendium & GW-170 & GW-205 \\
& GW-620 & GW-679 \\
& & GW-757 \\
\hline
\end{tabular}

Redevelopment of these wells prior to sampling is recommended to ensure collection of the most representative (i.e., the least grout-contaminated) groundwater samples.

\subsubsection{Water Level Fluctuation}

This characteristic applies to wells that have presampling groundwater elevations which exhibit unusually wide fluctuations. The value shown on the Summary Cover Sheet is the difference (in $\mathrm{ft}$ ) between maximum and minimum depth-to-water measurements recorded during successive quarterly or semiannual groundwater sampling events. Substantial temporal (seasonal) variations in the groundwater elevations may suggest that the monitored interval in the well intercepts highly permeable and well-connected groundwater flowpaths. Typically, wells located in the Chestnut Ridge Regime have higher water level fluctuations than wells located in the Bear Creek or East Fork Regimes. The following 22 wells, most of which are located in the Chestnut Ridge Regime, have seasonal water level fluctuations greater than $25 \mathrm{ft}$.

Table 3. Wells that exhibit wide water-level fluctuations

\begin{tabular}{|c|c|ccc|}
\hline $\begin{array}{c}\text { BEAR CREEK } \\
\text { REGIME }\end{array}$ & $\begin{array}{c}|c| \\
\text { EAST FORK } \\
\text { REGIME }\end{array}$ & \multicolumn{3}{c|}{ REGIME } \\
\hline GW-123 & GW-253 & 1090 & GW-522 & GW-742 \\
GW-923 & GW-698 & GW-173 & GW-540 & GW-743 \\
& GW-735 & GW-180 & GW-544 & GW-796 \\
& & GW-322 & GW-560 & GW-798 \\
& & GW-339 & GW-608 & GW-801 \\
\hline
\end{tabular}




\subsubsection{Total Dissolved Solids (TDS)}

This characteristic applies to wells, listed in Table 4, that yield groundwater samples with unusually high ( $>850$ milligrams per liter $[\mathrm{mg} / \mathrm{L}])$ or low TDS $(<150 \mathrm{mg} / \mathrm{L})$, as determined from average values reported for the samples collected since January 1990 (excluding suspected outliers).

Table 4. Wells that yield groundwater with unusually high or unusually low TDS

\begin{tabular}{|c|c|c|c|c|c|c|}
\hline $\begin{array}{c}\text { WELL } \\
\text { LOCATION }\end{array}$ & $\begin{array}{l}\text { WELL DEPTH } \\
\text { (ft bgs) }\end{array}$ & \multicolumn{3}{|c|}{$\begin{array}{c}\text { HIGH TDS } \\
(\text { Average }>850 \mathrm{mg} / \mathrm{L})\end{array}$} & \multirow{2}{*}{\multicolumn{2}{|c|}{$\begin{array}{c}\text { LOW TDS } \\
\text { (Average }<\mathbf{1 5 0} \text { mg/L) } \\
\text { GW-008 } \\
\text { GW-237 }\end{array}$}} \\
\hline \multirow[t]{3}{*}{$\begin{array}{l}\text { Bear Creek } \\
\text { Regime }\end{array}$} & $<20$ & $\begin{array}{l}\text { GW-10 } \\
\text { GW-10 } \\
\text { GW-10 }\end{array}$ & 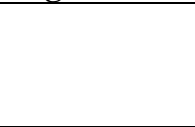 & $\begin{array}{l}\text { GW-276 } \\
\text { GW-537 }\end{array}$ & & \\
\hline & $20-200$ & $\begin{array}{l}\text { GW-085 } \\
\text { GW-106 } \\
\text { GW-108 } \\
\text { GW-109 } \\
\text { GW-122 }\end{array}$ & $\begin{array}{c}\text { GW-134-33 } \\
\text { GW-134-35 } \\
\text { GW-134-36 } \\
\text { GW-229 } \\
\text { GW-244 } \\
\text { GW-245 }\end{array}$ & $\begin{array}{r}\text { GW-246 } \\
\text { GW-247 } \\
\text { GW-277 } \\
\text { GW-346 } \\
\text { GW-526 }\end{array}$ & & \\
\hline & $>200$ & $\begin{array}{c}\text { GW-071 } \\
\text { GW-123 } \\
\text { GW-133-01 } \\
\text { GW-134-05 } \\
\text { GW-134-11 } \\
\text { GW-134-15 } \\
\text { GW-134-18 }\end{array}$ & $\begin{array}{l}\text { GW-134-21 } \\
\text { GW-134-25 } \\
\text { GW-135-03 } \\
\text { GW-135-06 } \\
\text { GW-135-11 } \\
\text { GW-135-23 } \\
\text { GW-135-26 }\end{array}$ & $\begin{array}{l}\text { GW-615 } \\
\text { GW-616 } \\
\text { GW-623 } \\
\text { GW-710 } \\
\text { GW-711 }\end{array}$ & & \\
\hline \multirow[t]{2}{*}{$\begin{array}{l}\text { East Fork } \\
\text { Regime }\end{array}$} & $<20$ & $\begin{array}{r}55-1 \mathrm{~A} \\
55-2 \mathrm{~A} \\
\mathrm{GW}-27\end{array}$ & & $\begin{array}{l}\text { GW-633 } \\
\text { GW-691 }\end{array}$ & $\begin{array}{c}56-4 A \\
\text { GW-269 } \\
\text { GW-273 } \\
\text { GW-508 }\end{array}$ & $\begin{array}{l}\text { GW-617 } \\
\text { GW-761 } \\
\text { GW-787 }\end{array}$ \\
\hline & $20-200$ & $\begin{array}{c}55-2 \mathrm{~B} \\
55-2 \mathrm{C} \\
\mathrm{GW}-253 \\
\end{array}$ & $\begin{array}{l}\text { GW-274 } \\
\text { GW-275 } \\
\text { GW-690 }\end{array}$ & GW-698 & \multicolumn{2}{|c|}{ GW-619 } \\
\hline \multirow[t]{2}{*}{$\begin{array}{l}\text { Chestnut } \\
\text { Ridge } \\
\text { Regime }\end{array}$} & $20-200$ & & $\cdot$ & & $\begin{array}{l}\text { GW-300 } \\
\text { GW-521 } \\
\text { GW-542 } \\
\text { GW-564 }\end{array}$ & $\begin{array}{l}\text { GW-796 } \\
\text { GW-798 } \\
\text { GW-799 } \\
\text { GW-801 }\end{array}$ \\
\hline & $>200$ & & & & \multicolumn{2}{|c|}{ GW-608 } \\
\hline
\end{tabular}

For some wells, the high TDS reflects the degree of groundwater contamination, particularly wells located near the former S-3 Ponds. However, other wells yield uncontaminated groundwater with unusually high TDS, including most of the deepest wells at Y-12 (TDS increases with depth) and shallower wells completed with monitored intervals that do not intercept highly permeable groundwater flowpaths. Similarly, some wells that monitor contaminated and uncontaminated groundwater yield samples with unusually low TDS, which is believed to reflect the relatively short residence time of the groundwater and implies that the wells intercept highly permeable and hydraulically active groundwater flowpaths. 


\subsubsection{Low pH}

This characteristic applies to wells that yield groundwater samples with acidic $\mathrm{pH}(<5.5$ standard units). Average $\mathrm{pH}$ values determined from data (field measurements) obtained during sampling events performed since January 1990 (excluding suspected outliers) show that, as summarized below in Table 5, twelve wells yield such acidic groundwater, most of which are located in the Bear Creek Regime.

Table 5. Wells that yield acidic groundwater samples.

\begin{tabular}{|cc|cc|c|}
\hline \multicolumn{2}{|c|}{$\begin{array}{c}\text { BEAR CREEK } \\
\text { REGIME }\end{array}$} & \multicolumn{2}{c|}{$\begin{array}{c}\text { EAST FORK } \\
\text { REGIME }\end{array}$} & $\begin{array}{c}\text { CHESTNUT RIDGE } \\
\text { REGIME }\end{array}$ \\
\hline GW-008 & GW-246 & GW-108 & GW-273 & \\
GW-046 & GW-276 & GW-109 & GW-508 & \\
GW-236 & GW-531 & GW-253 & GW-633 & \\
GW-243 & GW-653 & & & \\
\hline
\end{tabular}

Most of these wells (GW-108, GW-109, GW-236, GW-243, GW-246, GW-273, GW-276, and GW-633) monitor the highly contaminated, acidic groundwater in the aquitard formations (e.g., Nolichucky Shale) near the west end of Y-12 that is a legacy of the historical operation of the former S-3 Ponds. Other wells that yield groundwater samples with acidic $\mathrm{pH}$ (e.g., GW-008, GW-046, and GW-653) monitor groundwater contaminated by chlorinated hydrocarbons, with the low $\mathrm{pH}$ being an indicator of ongoing chemical and/or biologically-mediated degradation of the compounds.

\subsubsection{Sampling Method Sensitivity}

This characteristic applies to wells that yield groundwater samples with substantially different contaminant concentrations depending on the groundwater sampling method. An evaluation of the monitoring data available through August 2000 indicated potential bias related to the groundwater sampling method for 18 monitoring wells (BWXT 2001). Monitoring results obtained since CY 2000 for eight additional wells that had insufficient data for the original study likewise suggested potential sampling method bias. To confirm the apparent bias, the Y-12 GWPP uses a "paired" groundwater sampling approach, whereby the low-flow sampling method is used to collect a sample one day and the conventional sampling method is used to collect a sample the next day. Both samples are then analyzed for the same suite of analytes. As shown below on Table 6, paired sampling results have "confirmed" the sampling method bias for 12 wells and "disproved" the sampling bias for seven wells, with "suspected" sampling method bias pending results of paired sampling. Notably, results of paired sampling at well GW-225 disproved the suspected sampling method bias (higher conventional sampling results) for nitrate concentrations, but identified sampling method bias for VOC concentrations (Table 6). 
Table 6. Wells evaluated for apparent sampling method bias

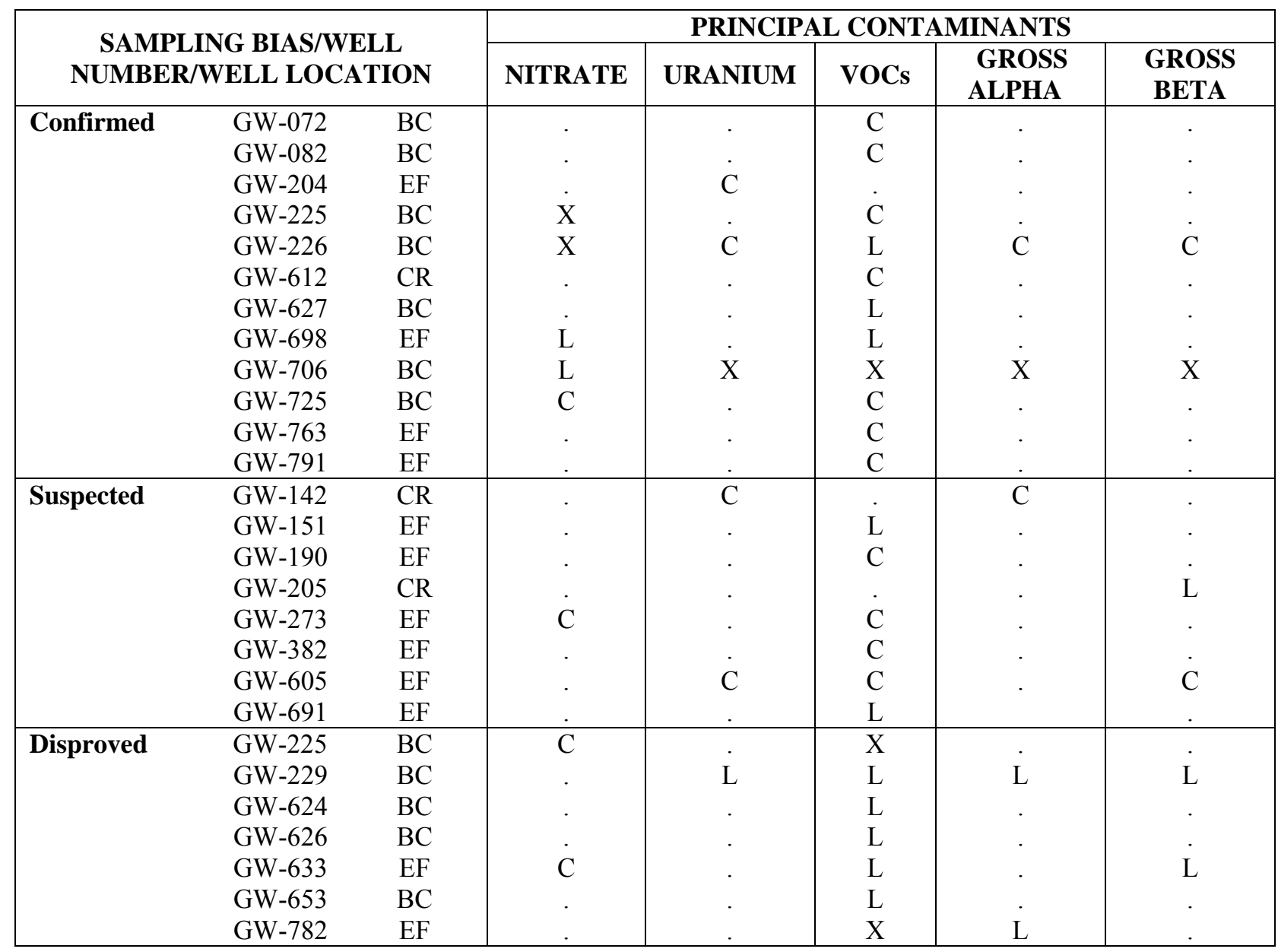

Note:

Confirmed $=$ Results of paired sampling confirm the significant difference between concentrations of specified contaminants detected in samples obtained with the conventional sampling and low-flow sampling methods.

Suspected $=$ Historical data show a significant difference between concentrations of specified contaminants detected in samples obtained with the conventional sampling and low-flow sampling methods, but paired sampling results not needed for confirmation.

Disproved $=$ Results of paired sampling do not support the significant difference in the concentrations of specified contaminants indicated by historical conventional and low-flow sampling results.

$\mathrm{BC}=$ Bear Creek Regime

$\mathrm{EF}=$ East Fork Regime

$\mathrm{CR}=$ Chestnut Ridge Regime

“. = Not a contaminant in the groundwater at the well.

$\mathrm{X}=\mathrm{A}$ contaminant in the groundwater at the well, but there is no clear significant difference between conventional sampling and low-flow sampling results.

$\mathrm{C}=$ Conventional sampling results show significantly higher concentrations of specified contaminant.

$\mathrm{L}=$ Low-flow sampling results show significantly higher concentrations of specified contaminant. 


\subsubsection{Other Characteristics}

This characteristic applies to wells that exhibit other distinguishing groundwater sampling characteristics. For example, a well located in the East Fork Regime near the west end of Y-12 (GW-108) yields groundwater samples that effervesce, indicating unusual geochemistry and water quality. Where other distinctive sampling characteristics exist, a detailed discussion of the sampling characteristic(s), including a summary of the applicable geochemical data and/or hydrograph of applicable hydrologic data, is provided in the appropriate section of the data evaluation for the well.

\subsection{PRINCIPAL CONTAMINANTS}

This section of the Summary Cover Sheet provides a summary of the analytical data obtained for the well since January 1991 regarding the concentrations of the principal groundwater contaminants at Y-12: nitrate, uranium, VOCs, gross alpha activity, and gross beta activity. The data summary for each contaminant includes the number of samples (since January 1991) with concentrations that meet the data quality objectives of the Y-12 GWPP and exceed the respective screening levels listed in Table 7; the historical maximum concentration of each contaminant (and associated sampling date); and the long-term contaminant concentration trend (increasing, decreasing, or indeterminate).

Table 7. Principal contaminants and corresponding screening levels

\begin{tabular}{|l|l|}
\hline \multicolumn{1}{|c|}{ CONTAMINANT } & \multicolumn{1}{|c|}{ SCREENING LEVEL } \\
\hline Nitrate (as N) & $10 \mathrm{mg} / \mathrm{L}$ \\
Uranium & $0.03 \mathrm{mg} / \mathrm{L}$ \\
Summed VOCs & $5 \mathrm{micrograms}$ per liter $(\mu \mathrm{g} / \mathrm{L})$ \\
Gross alpha activity & $15 \mathrm{picoCuries} \mathrm{per} \mathrm{liter}(\mathrm{pCi} / \mathrm{L})$ \\
Gross beta activity & $50 \mathrm{pCi} / \mathrm{L}$ \\
\hline
\end{tabular}

Each respective screening level for nitrate, total uranium, and gross alpha activity is the Safe Drinking Water Act (SDWA) maximum contaminant level (MCL) for drinking water. The screening level for summed VOCs is set at a common MCL value. The screening level for gross beta activity is the SDWA screening value for a 4 millirem per year dose equivalent (the MCL for gross beta activity).

The maximum contaminant concentration reported for the location for the most recent revision to the Y-12 GWPP Compendium (see Section 1.3) is shown in a row of boxes located in the upper right corner of each Summary Cover Sheet. The contaminant levels that may be presented in the boxes are shown below in Table 8 .

Table 8. Explanation for the principal contaminant concentration summary

\begin{tabular}{|c|c|c|c|c|c|}
\hline CONTAMINANT & $\begin{array}{c}\text { NITRATE } \\
(\mathrm{mg} / \mathrm{L})\end{array}$ & $\begin{array}{c}\text { URANIUM } \\
\text { (mg/L) }\end{array}$ & $\begin{array}{c}\text { SUMMED VOCs } \\
(\mu \mathrm{g} / \mathrm{L})\end{array}$ & $\begin{array}{c}\text { GROSS ALPHA } \\
(\mathrm{pCi} / \mathrm{L})\end{array}$ & $\begin{array}{c}\text { GROSS BETA } \\
(\mathrm{pCi} / \mathrm{L})\end{array}$ \\
\hline $\begin{array}{c}\text { Box Options/ } \\
\text { Contaminant } \\
\text { Concentration } \\
\text { Range }\end{array}$ & $\begin{array}{c}\mathrm{ND} \\
<5 \\
5-10 \\
10-100 \\
100-1,000 \\
>1,000\end{array}$ & $\begin{array}{c}\mathrm{ND} \\
<0.015 \\
0.015-0.03 \\
0.03-0.3 \\
0.3-3.0 \\
>3\end{array}$ & $\begin{array}{c}\cdot \dot{N D} \\
<5 \\
5-50 \\
50-500 \\
500-5,000 \\
>5,000\end{array}$ & $\begin{array}{c}\dot{N D} \\
<7.5 \\
7.5-15 \\
15-150 \\
150-1,500 \\
>1,500\end{array}$ & $\begin{array}{c}\text { ND } \\
<25 \\
25-50 \\
50-500 \\
500-5,000 \\
>5,000\end{array}$ \\
\hline Screening Level & 10 & 0.03 & 5 & 15 & 50 \\
\hline
\end{tabular}




\subsection{DATA EVALUATION NARRATIVE}

In conjunction with the Summary Cover Sheet for each applicable sampling location (see Section 1.1), each Brief in the Y-12 GWPP compendium provides a narrative description and evaluation of the hydrologic and groundwater quality data obtained to date. Each narrative follows a standard format that generally mirrors the corresponding Summary Cover Sheet. The following sections provide background information regarding the contents of the Data Evaluation Narrative for each monitoring well, which also address corresponding contents of the Data Evaluation Narrative for each spring and surface water station.

As detailed below, the Data Evaluation Narrative for each monitoring well included in the Y-12 GWPP compendium contains separate subsections regarding: (1) the installation, construction, and location of the well; (2) the sampling history for the well, including detailed descriptions of any distinguishing sampling characteristics; (3) the hydrologic characteristics of the well; (4) the geochemical characteristics of the groundwater samples from the well; (5) the concentrations and characteristics (e.g., long-term concentration trends) of the principal Y-12 groundwater contaminants in the well; and (6) the list of referenced technical reports and documents. Applicable subsections of the Data Evaluation Narrative define site-specific and other "special" acronyms and abbreviations, but the following "universal" acronyms and abbreviations are not defined.

$\begin{array}{lll}\text { bgs } & - & \text { below ground surface } \\ \text { CERCLA } & - & \text { Comprehensive Environmental Response, Compensation, and Liability Act } \\ \text { DOE } & - & \text { U.S. Department of Energy } \\ \text { EPA } & - & \text { U.S. Environmental Protection Agency } \\ \mathrm{ft} & - & \text { feet } \\ \mathrm{msl} & - & \text { mean sea level } \\ \mathrm{mg} / \mathrm{L} & - & \text { milligrams per liter } \\ \mu \mathrm{g} / \mathrm{L} & - & \text { micrograms per liter } \\ \mathrm{PVC} & - & \text { polyvinyl chloride } \\ \mathrm{pCi} / \mathrm{L} & - & \text { picoCuries per liter } \\ \text { RCRA } & - & \text { Resource Conservation and Recovery Act } \\ \text { ROD } & - & \text { record of decision } \\ \text { SDWA } & - & \text { Safe Drinking Water Act }\end{array}$

\subsection{INSTALLATION, CONSTRUCTION, AND LOCATION}

This subsection of the Data Evaluation Narrative for each well provides a description of the location of the well, including a brief description of the applicable functional area (or other nearby topographic/geographic/cultural features), and a short overview of the construction of well. Unless noted otherwise, geographic directions are in reference to the Y-12 Administrative Grid. For wells that monitor contaminated groundwater, this section commonly provides a description of the site that is the known or suspected source of the contamination. 


\subsection{SAMPLING HISTORY AND CHARACTERISTICS}

This subsection of the Data Evaluation Narrative for each monitoring well describes the groundwater sampling history for the well, including the initial and most recent sampling dates of the current revision (see Section 1.3) for each applicable groundwater sampling method (conventional sampling and low-flow sampling). Additionally, if the well exhibits any of the sampling characteristics noted on the Summary Cover Sheet, as defined in Section 2.6, this subsection presents a detailed description of the sampling characteristic(s), including data summary tables and/or trend charts.

\subsection{HYDROLOGIC CHARACTERISTICS}

This subsection of the Data Evaluation Narrative for each monitoring well describes the hydrologic characteristics of the well, including an overview of local hydrogeology, a summary of available hydraulic data for the well (e.g., hydraulic conductivity test results), the typical depth to the static water level in the well, and the range of water level fluctuations in the well. Hydrographs of presampling groundwater elevations are provided for wells that exhibit unusually large $(>25 \mathrm{ft})$ water level fluctuations or other distinctive short- or long-term changes in static water levels in the well.

\subsection{GEOCHEMICAL CHARACTERISTICS}

This subsection of the Data Evaluation Narrative for each monitoring well describes the geochemical characteristics of the groundwater samples from the well, including the range of TDS reported for the samples; the range of field $\mathrm{pH}$ measurements associated with each sampling event; the major-ion chemistry of the groundwater samples; and the typical concentrations of trace metals detected in the samples. The hydrochemical facies (e.g., calcium-magnesium bicarbonate), as calculated from milliequivalent proportions for a Piper Diagram (Fetter 1994), is provided in this section. Additional information, including applicable data summary tables and/or time-series plots, is provided for wells that yield groundwater samples with: (1) unusually high or unusually low TDS; (2) strongly basic $\mathrm{pH}$ and other geochemical indicators of localized grout contamination; or (3) unusually high concentrations of major ions (e.g., chloride).

\subsection{CONTAMINATION}

This subsection of the Data Evaluation Narrative for each monitoring well presents separate descriptions of the analytical data for each of the primary groundwater contaminants at Y-12 (nitrate, uranium, VOCs, gross alpha activity, and gross beta activity) and a detailed evaluation of the results. For some wells, another section is included for other notable contaminants (primarily trace metals) that may be present in the groundwater at the well. The data evaluation includes analytical results that meet data quality objectives, as defined in the Y-12 GWPP Data Management Plan (BWXT 2006b). Where applicable, the data evaluation for each groundwater contaminant includes data summary tables and trend graphs. 
The following "universal" acronyms and abbreviations are used without being defined in the applicable subsection of the narrative for monitoring locations.

$\begin{array}{lll}\text { CE } & - & \begin{array}{l}\text { counting error (samples collected 1990-2005), or } \\ \text { total propagated uncertainty (samples collected since January 2006) }\end{array} \\ \text { CTET } & - & \text { carbon tetrachloride } \\ \text { MC } & - & \text { methylene chloride } \\ \text { MDA } & - & \text { minimum detectable activity } \\ \text { PCE } & - & \text { tetrachloroethene } \\ \text { TCE } & - & \text { trichloroethene } \\ \text { TCFM } & - & \text { trichlorofluoromethane } \\ \text { VC } & - & \text { Vinyl chloride } \\ \text { 111TCA } & - & 1,1,1 \text {-trichloroethane } \\ \text { 11DCA } & - & 1,1 \text {-dichloroethane } \\ \text { 11DCE } & - & 1,1 \text {-dichloroethene } \\ \text { 12DCA } & - & 1,2-\text { dichloroethane } \\ \text { 12DCE } & - & 1,2-\text { dichloroethene } \\ \text { c12DCE } & - & \text { cis-1,2-dichloroethene } \\ \text { t12DCE } & - & \text { trans-1,2-dichloroethene }\end{array}$




\subsection{REFERENCES}

BWXT Y-12, L.L.C. (BWXT). 2001. Groundwater Monitoring Data Evaluation Report for the U.S. Department of Energy Y-12 National Security Complex, Oak Ridge, Tennessee, Appendix C: Groundwater Sampling Method Sensitivity Evaluation for the Y-12 Groundwater Protection Program, Y/SUB/02-012529/2, September 2002.

BWXT. 2003. Updated Subsurface Data Base for Bear Creek Valley, Chestnut Ridge, and Parts of Bethel Valley on the U.S. Department of Energy Oak Ridge Reservation, Y/TS-881/R5, February 2003.

BWXT. 2006b. Y-12 Groundwater Protection Program Data Management Plan, Y/TS-2007, Revision 3, December 2006.

Babcock \& Wilcox Technical Services Y-12, LLC (B\&W Y-12). 2009a. Groundwater Protection Program Management Plan for the U.S. Department of Energy Y-12 National Security Complex, Oak Ridge, Tennessee, Y/SUB/01-006512/2/R2, January 2009.

B\&W Y-12. 2009b Y-12 Groundwater Protection Program Monitoring Optimization Plan for Groundwater Monitoring Wells at the U.S. Department of Energy Y-12 National Security Complex, Oak Ridge, Tennessee, Y/TS-2031/R1, December 2009.

Fetter, C.W. 1994. Applied Hydrogeology, Third Edition. Macmillan College Publishing Company, Inc. New York, New York. p. 421-423. 
APPENDIX A

FIGURES 


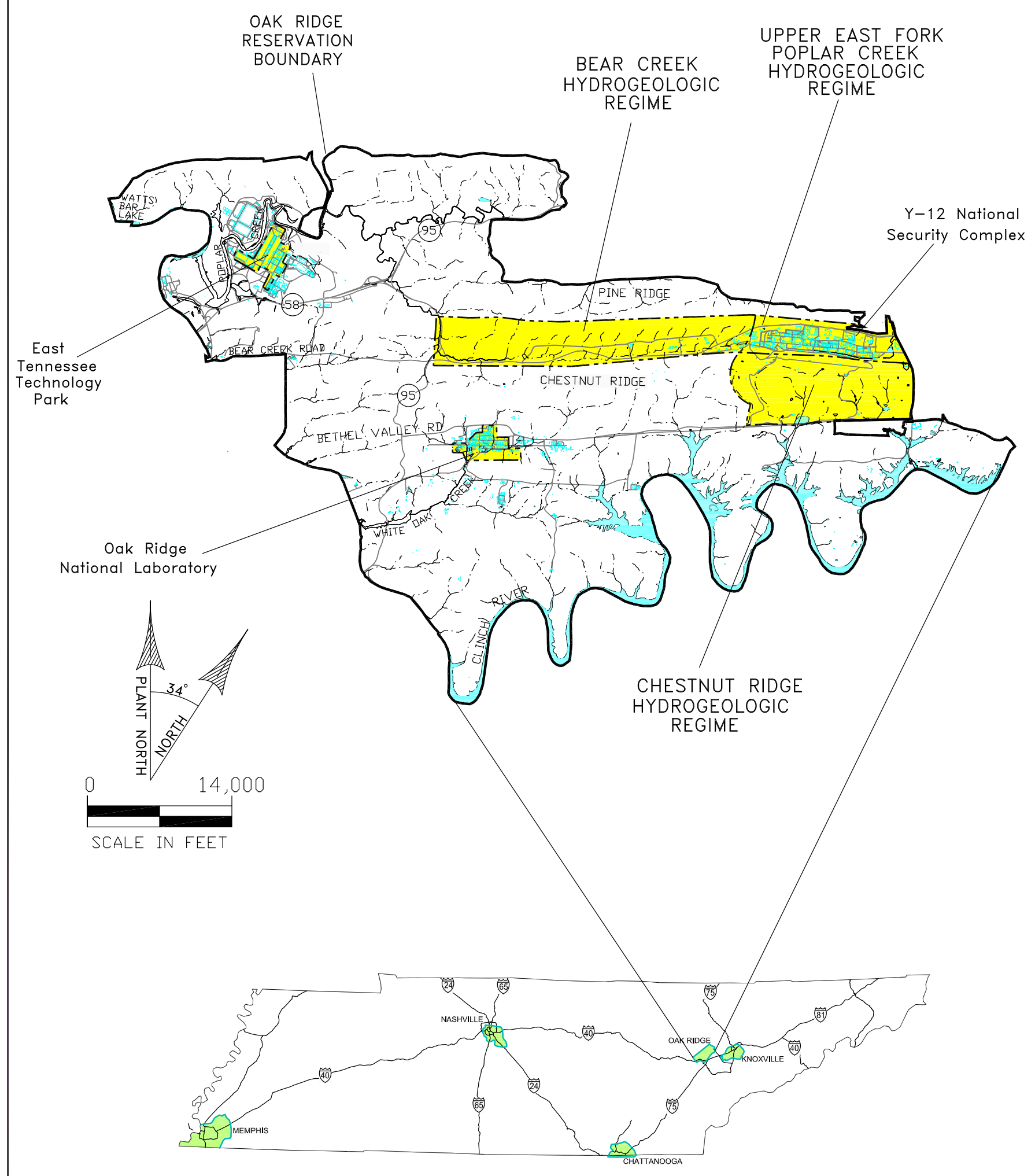

GWPP Fig1 09/23/08

Fig. A.1. Hydrogeologic regimes at the Y-12 National Security Complex. 


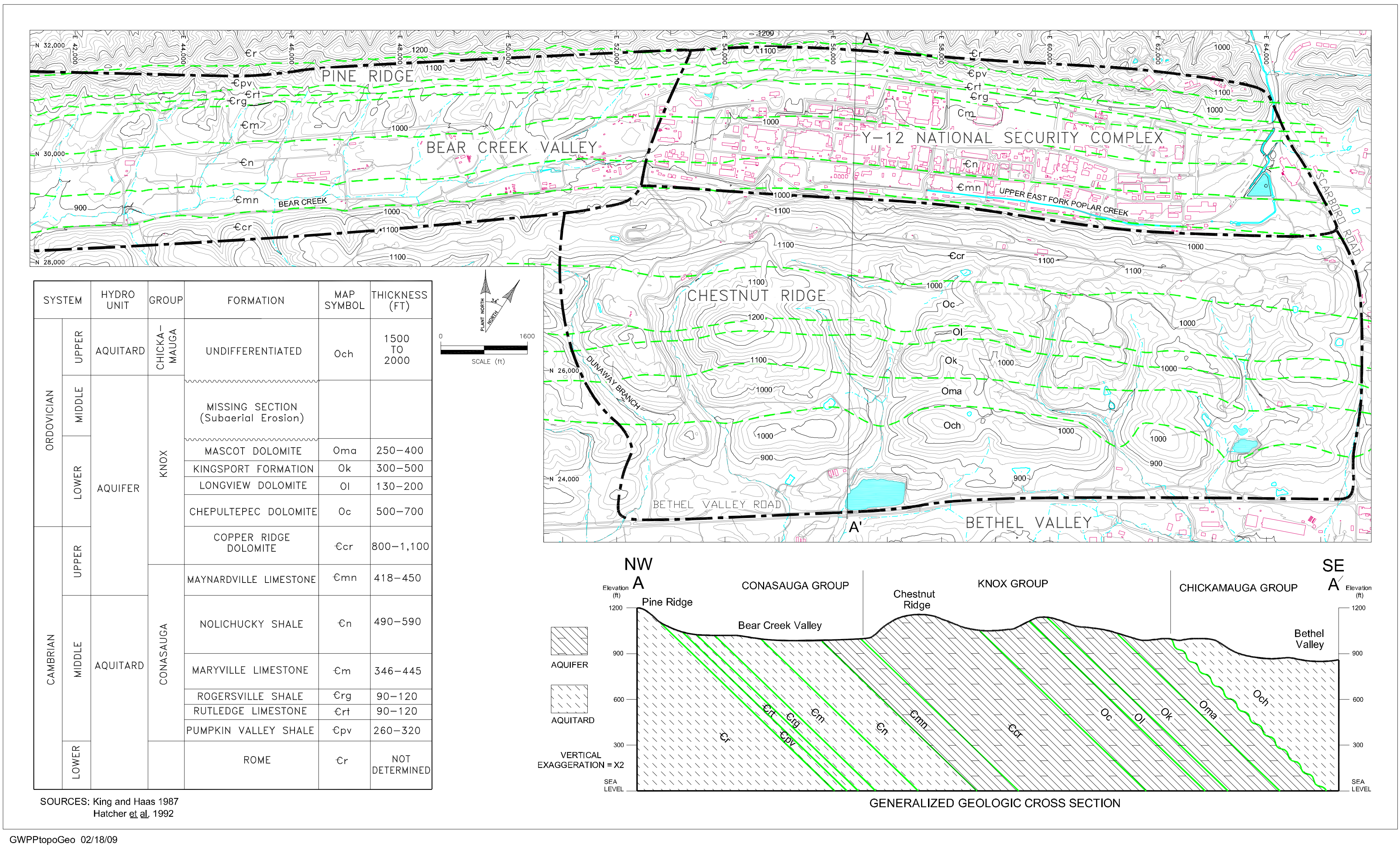


APPENDIX B

TABLES 
Table B.1. Index of monitoring wells included in Volume 2 of the Y-12 GWPP Compendium

\begin{tabular}{|c|c|c|c|c|c|c|c|c|}
\hline $\begin{array}{c}\text { Monitoring } \\
\text { Well } \\
\end{array}$ & Regime & $\begin{array}{c}\text { Revision } \\
\text { Year }\end{array}$ & $\begin{array}{c}\text { Monitoring } \\
\text { Well }\end{array}$ & Regime & $\begin{array}{c}\text { Revision } \\
\text { Year } \\
\end{array}$ & $\begin{array}{c}\text { Monitoring } \\
\text { Well }\end{array}$ & Regime & $\begin{array}{c}\text { Revision } \\
\text { Year } \\
\end{array}$ \\
\hline 1090 & CR & 2006 & GW-068 & $\mathrm{BC}$ & 2006 & GW-134-33 & $\mathrm{BC}$ & 2004 \\
\hline $55-1 \mathrm{~A}$ & $\mathrm{EF}$ & 2006 & GW-071 & $\mathrm{BC}$ & 2006 & GW-134-35 & $\mathrm{BC}$ & 2004 \\
\hline $55-2 \mathrm{~A}$ & $\mathrm{EF}$ & 2006 & GW-072 & $\mathrm{BC}$ & 2005 & GW-134-36 & BC & 2004 \\
\hline $55-2 B$ & $\mathrm{EF}$ & 2006 & GW-077 & BC & 2006 & GW-135-03 & BC & 2004 \\
\hline $55-2 C$ & $\mathrm{EF}$ & 2006 & GW-078 & BC & 2006 & GW-135-06 & BC & 2004 \\
\hline $55-3 \mathrm{~A}$ & $\mathrm{EF}$ & 2006 & GW-079 & BC & 2006 & GW-135-11 & BC & 2004 \\
\hline $55-3 B$ & $\mathrm{EF}$ & 2006 & GW-080 & BC & 2006 & GW-135-15 & BC & 2004 \\
\hline $55-3 C$ & $\mathrm{EF}$ & 2006 & GW-082 & $\mathrm{BC}$ & 2006 & GW-135-19 & BC & 2004 \\
\hline $55-6 \mathrm{~A}$ & $\mathrm{EF}$ & 2004 & GW-085 & $\mathrm{BC}$ & 2006 & GW-135-23 & BC & 2004 \\
\hline $56-1 \mathrm{~A}$ & $\mathrm{EF}$ & 2006 & GW-089 & BC & 2008 & GW-135-26 & BC & 2004 \\
\hline $56-1 C$ & $\mathrm{EF}$ & 2008 & GW-097 & $\mathrm{BC}$ & 2005 & GW-135-30 & $\mathrm{BC}$ & 2004 \\
\hline $56-2 \mathrm{~A}$ & $\mathrm{EF}$ & 2006 & GW-098 & $\mathrm{BC}$ & 2006 & GW-135-34 & $\mathrm{BC}$ & 2004 \\
\hline $56-2 B$ & $\mathrm{EF}$ & 2006 & GW-100 & $\mathrm{BC}$ & 2004 & GW-135-39 & BC & 2004 \\
\hline $56-2 C$ & $\mathrm{EF}$ & 2006 & GW-101 & $\mathrm{BC}$ & 2004 & GW-141 & CR & 2006 \\
\hline $56-3 \mathrm{~A}$ & $\mathrm{EF}$ & 2006 & GW-105 & EF & 2006 & GW-142 & CR & 2003 \\
\hline $56-3 B$ & $\mathrm{EF}$ & 2006 & GW-106 & EF & 2006 & GW-143 & CR & 2006 \\
\hline $56-3 C$ & $\mathrm{EF}$ & 2006 & GW-108 & $\mathrm{EF}$ & 2006 & GW-144 & CR & 2006 \\
\hline $56-4 \mathrm{~A}$ & EF & 2006 & GW-109 & $\mathrm{EF}$ & 2006 & GW-145 & CR & 2006 \\
\hline $56-6 A$ & $\mathrm{EF}$ & 2006 & GW-115 & $\mathrm{BC}$ & 2004 & GW-148 & EF & 2006 \\
\hline $56-8 \mathrm{~A}$ & $\mathrm{EF}$ & 2006 & GW-122 & BC & 2006 & GW-151 & $\mathrm{EF}$ & 2006 \\
\hline $60-1 \mathrm{~A}$ & $\mathrm{EF}$ & 2006 & GW-123 & $\mathrm{BC}$ & 2003 & GW-153 & EF & 2006 \\
\hline $59-1 \mathrm{~A}$ & $\mathrm{EF}$ & 2003 & GW-124 & $\mathrm{BC}$ & 2005 & GW-154 & $\mathrm{EF}$ & 2006 \\
\hline $59-1 B$ & $\mathrm{EF}$ & 2004 & GW-126 & $\mathrm{BC}$ & 2006 & GW-156 & CR & 2006 \\
\hline $59-1 \mathrm{C}$ & $\mathrm{EF}$ & 2003 & GW-127 & BC & 2005 & GW-159 & CR & 2006 \\
\hline $60-1 \mathrm{~A}$ & $\mathrm{EF}$ & 2006 & GW-133-01 & BC & 2004 & GW-161 & CR & 2008 \\
\hline $60-1 B$ & $\mathrm{EF}$ & 2003 & GW-133-05 & BC & 2004 & GW-169 & UV & 2006 \\
\hline $60-2 \mathrm{~A}$ & $\mathrm{EF}$ & 2003 & GW-133-08 & $\mathrm{BC}$ & 2004 & GW-170 & UV & 2006 \\
\hline GW-006 & $\mathrm{BC}$ & 2008 & GW-133-10 & BC & 2004 & GW-171 & UV & 2006 \\
\hline GW-008 & $\mathrm{BC}$ & 2006 & GW-133-14 & BC & 2004 & GW-172 & UV & 2006 \\
\hline GW-014 & $\mathrm{BC}$ & 2006 & GW-133-17 & $\mathrm{BC}$ & 2004 & GW-173 & CR & 2004 \\
\hline GW-046 & $\mathrm{BC}$ & 2006 & GW-133-21 & $\mathrm{BC}$ & 2004 & GW-174 & CR & 2008 \\
\hline GW-052 & BC & 2004 & GW-133-24 & $\mathrm{BC}$ & 2004 & GW-175 & CR & 2006 \\
\hline GW-053 & $\mathrm{BC}$ & 2005 & GW-134-05 & $\mathrm{BC}$ & 2004 & GW-176 & CR & 2004 \\
\hline GW-056 & BC & 2004 & GW-134-11 & BC & 2004 & GW-177 & CR & 2006 \\
\hline GW-058 & $\mathrm{BC}$ & 2006 & GW-134-15 & $\mathrm{BC}$ & 2004 & GW-178 & CR & 2006 \\
\hline GW-061 & BC & 2005 & GW-134-18 & $\mathrm{BC}$ & 2004 & GW-179 & CR & 2004 \\
\hline GW-064 & $\mathrm{BC}$ & 2005 & GW-134-21 & $\mathrm{BC}$ & 2004 & GW-180 & CR & 2008 \\
\hline GW-065 & $\mathrm{BC}$ & 2008 & GW-134-25 & $\mathrm{BC}$ & 2004 & GW-190 & $\mathrm{EF}$ & 2003 \\
\hline \multirow{2}{*}{ GW-066 } & BC & 2005 & GW-134-29 & $\mathrm{BC}$ & 2004 & GW-192 & EF & 2006 \\
\hline & & & & & & GW-193 & EF & 2006 \\
\hline
\end{tabular}

Notes:

$\mathrm{BC}=$ Bear Creek Hydrogeologic Regime

$\mathrm{CR}=$ Chestnut Ridge Hydrogeologic Regime

EF = Upper East Fork Poplar Creek Hydrogeologic Regime

$\mathrm{UV}=$ Union Valley (East of the EF Regime) 
Table B.2. Index of monitoring wells included in Volume 3 of the Y-12 GWPP Compendium

\begin{tabular}{|c|c|c|c|c|c|c|c|c|}
\hline $\begin{array}{c}\text { Monitoring } \\
\text { Well }\end{array}$ & Regime & $\begin{array}{c}\text { Revision } \\
\text { Year }\end{array}$ & $\begin{array}{c}\text { Monitoring } \\
\text { Well }\end{array}$ & Regime & $\begin{array}{c}\text { Revision } \\
\text { Year }\end{array}$ & $\begin{array}{c}\text { Monitoring } \\
\text { Well }\end{array}$ & Regime & $\begin{array}{c}\text { Revision } \\
\text { Year }\end{array}$ \\
\hline GW-203 & CR & 2006 & GW-289 & $\mathrm{BC}$ & 2006 & GW-542 & CR & 2006 \\
\hline GW-204 & $\mathrm{EF}$ & 2006 & GW-291 & $\mathrm{BC}$ & 2005 & GW-543 & CR & 2006 \\
\hline GW-205 & CR & 2006 & GW-292 & CR & 2008 & GW-544 & CR & 2006 \\
\hline GW-207 & $\mathrm{EF}$ & 2005 & GW-293 & CR & 2008 & GW-557 & CR & 2006 \\
\hline GW-208 & $\mathrm{EF}$ & 2005 & GW-294 & CR & 2008 & GW-560 & CR & 2006 \\
\hline GW-217 & CR & 2006 & GW-296 & CR & 2008 & GW-562 & CR & 2006 \\
\hline GW-219 & $\mathrm{EF}$ & 2005 & GW-298 & CR & 2008 & GW-564 & CR & 2006 \\
\hline GW-220 & $\mathrm{EF}$ & 2006 & GW-300 & CR & 2004 & GW-601 & BC & 2005 \\
\hline GW-221 & CR & 2006 & GW-301 & CR & 2006 & GW-605 & $\mathrm{EF}$ & 2006 \\
\hline GW-222 & $\mathrm{EF}$ & 2004 & GW-302 & CR & 2003 & GW-606 & $\mathrm{EF}$ & 2006 \\
\hline GW-223 & $\mathrm{EF}$ & 2006 & GW-305 & CR & 2006 & GW-608 & CR & 2008 \\
\hline GW-225 & BC & 2006 & GW-306 & $\mathrm{BC}$ & 2008 & GW-609 & CR & 2006 \\
\hline GW-226 & BC & 2006 & GW-307 & $\mathrm{BC}$ & 2005 & GW-610 & CR & 2004 \\
\hline GW-227 & BC & 2005 & GW-309 & BC & 2008 & GW-611 & CR & 2004 \\
\hline GW-228 & BC & 2005 & GW-310 & BC & 2006 & GW-612 & CR & 2006 \\
\hline GW-229 & BC & 2006 & GW-311 & BC & 2006 & GW-615 & BC & 2006 \\
\hline GW-230 & UV & 2006 & GW-312 & BC & 2005 & GW-616 & BC & 2006 \\
\hline GW-231 & CR & 2006 & GW-313 & BC & 2005 & GW-617 & $\mathrm{EF}$ & 2006 \\
\hline GW-232 & UV & 2006 & GW-314 & BC & 2008 & GW-618 & $\mathrm{EF}$ & 2006 \\
\hline GW-236 & BC & 2004 & GW-315 & BC & 2006 & GW-619 & $\mathrm{EF}$ & 2006 \\
\hline GW-237 & $\mathrm{BC}$ & 2004 & GW-322 & CR & 2006 & GW-620 & $\mathrm{EF}$ & 2006 \\
\hline GW-240 & $\mathrm{EF}$ & 2006 & GW-332 & $\mathrm{EF}$ & 2006 & GW-623 & BC & 2008 \\
\hline GW-242 & $\mathrm{BC}$ & 2005 & GW-336 & $\mathrm{EF}$ & 2006 & GW-624 & $\mathrm{BC}$ & 2005 \\
\hline GW-244 & BC & 2005 & GW-337 & $\mathrm{EF}$ & 2006 & GW-626 & BC & 2006 \\
\hline GW-245 & BC & 2005 & GW-339 & CR & 2003 & GW-627 & BC & 2006 \\
\hline GW-246 & BC & 2006 & GW-346 & BC & 2005 & GW-629 & BC & 2006 \\
\hline GW-247 & BC & 2005 & GW-363 & BC & 2006 & GW-631 & $\mathrm{EF}$ & 2003 \\
\hline GW-251 & $\mathrm{EF}$ & 2006 & GW-364 & BC & 2005 & GW-633 & $\mathrm{EF}$ & 2006 \\
\hline GW-253 & $\mathrm{EF}$ & 2006 & GW-365 & BC & 2005 & GW-639 & BC & 2006 \\
\hline GW-257 & BC & 2006 & GW-367 & $\mathrm{BC}$ & 2008 & GW-648 & $\mathrm{BC}$ & 2008 \\
\hline GW-259 & BC & 2008 & GW-368 & BC & 2005 & GW-653 & BC & 2006 \\
\hline GW-265 & $\mathrm{EF}$ & 2006 & GW-369 & BC & 2008 & GW-656 & $\mathrm{EF}$ & 2006 \\
\hline GW-269 & $\mathrm{EF}$ & 2006 & GW-380 & $\mathrm{EF}$ & 2006 & GW-658 & $\mathrm{EF}$ & 2006 \\
\hline GW-270 & $\mathrm{EF}$ & 2003 & GW-381 & $\mathrm{EF}$ & 2006 & GW-679 & CR & 2004 \\
\hline GW-271 & $\mathrm{EF}$ & 2003 & GW-382 & $\mathrm{EF}$ & 2006 & GW-680 & CR & 2004 \\
\hline GW-272 & $\mathrm{EF}$ & 2003 & GW-383 & EF & 2006 & GW-683 & BC & 2006 \\
\hline GW-273 & $\mathrm{EF}$ & 2003 & GW-505 & $\mathrm{EF}$ & 2003 & GW-684 & BC & 2006 \\
\hline GW-274 & $\mathrm{EF}$ & 2006 & GW-508 & $\mathrm{EF}$ & 2008 & GW-686 & EF & 2006 \\
\hline GW-275 & $\mathrm{EF}$ & 2006 & GW-513 & CR & 2004 & GW-690 & $\mathrm{EF}$ & 2006 \\
\hline GW-276 & BC & 2006 & GW-514 & CR & 2006 & GW-691 & $\mathrm{EF}$ & 2006 \\
\hline GW-277 & BC & 2005 & GW-521 & CR & 2006 & GW-692 & $\mathrm{EF}$ & 2006 \\
\hline GW-281 & $\mathrm{EF}$ & 2006 & GW-522 & CR & 2006 & GW-694 & BC & 2006 \\
\hline GW-286 & BC & 2005 & GW-526 & $\mathrm{BC}$ & 2006 & GW-695 & BC & 2006 \\
\hline GW-287 & BC & 2005 & GW-531 & BC & 2008 & GW-696 & $\mathrm{EF}$ & 2003 \\
\hline \multirow[t]{2}{*}{ GW-288 } & $\mathrm{BC}$ & 2005 & GW-537 & BC & 2006 & GW-698 & $\mathrm{EF}$ & 2006 \\
\hline & & & GW-540 & CR & 2006 & & & \\
\hline
\end{tabular}

Notes:

$\mathrm{BC}=$ Bear Creek Hydrogeologic Regime

$\mathrm{CR}=$ Chestnut Ridge Hydrogeologic Regime

EF = Upper East Fork Poplar Creek Hydrogeologic Regime

$\mathrm{UV}=$ Union Valley (East of the EF Regime) 
Table B.3. Index of monitoring wells included in Volume 4 of the Y-12 GWPP Compendium

\begin{tabular}{|c|c|c|c|c|c|c|c|c|}
\hline $\begin{array}{c}\text { Monitoring } \\
\text { Well }\end{array}$ & Regime & $\begin{array}{c}\text { Revision } \\
\text { Year }\end{array}$ & $\begin{array}{c}\text { Monitoring } \\
\text { Well }\end{array}$ & Regime & $\begin{array}{c}\text { Revision } \\
\text { Year }\end{array}$ & $\begin{array}{c}\text { Monitoring } \\
\text { Well }\end{array}$ & Regime & $\begin{array}{c}\text { Revision } \\
\text { Year }\end{array}$ \\
\hline GW-700 & EF & 2006 & GW-740 & $\mathrm{BC}$ & 2006 & GW-801 & CR & 2006 \\
\hline GW-703 & BC & 2006 & GW-742 & CR & 2004 & GW-802 & EF & 2006 \\
\hline GW-704 & BC & 2006 & GW-743 & CR & 2004 & GW-816 & $\mathrm{EF}$ & 2006 \\
\hline GW-706 & $\mathrm{BC}$ & 2006 & GW-744 & $\mathrm{EF}$ & 2006 & GW-818 & $\mathrm{EF}$ & 2004 \\
\hline GW-709 & CR & 2006 & GW-747 & $\mathrm{EF}$ & 2006 & GW-820 & $\mathrm{EF}$ & 2006 \\
\hline GW-710 & $\mathrm{BC}$ & 2003 & GW-748 & $\mathrm{EF}$ & 2006 & GW-827 & CR & 2006 \\
\hline GW-711 & $\mathrm{BC}$ & 2003 & GW-749 & $\mathrm{EF}$ & 2006 & GW-829 & $\mathrm{BC}$ & 2006 \\
\hline GW-712 & $\mathrm{BC}$ & 2006 & GW-750 & $\mathrm{EF}$ & 2005 & GW-831 & CR & 2006 \\
\hline GW-713 & $\mathrm{BC}$ & 2006 & GW-757 & CR & 2006 & GW-832 & $\mathrm{EF}$ & 2006 \\
\hline GW-714 & $\mathrm{BC}$ & 2006 & GW-760 & $\mathrm{EF}$ & 2004 & GW-835 & $\mathrm{BC}$ & 2003 \\
\hline GW-715 & $\mathrm{BC}$ & 2004 & GW-761 & $\mathrm{EF}$ & 2003 & GW-916 & $\mathrm{BC}$ & 2006 \\
\hline GW-722-06 & $\mathrm{EF}$ & 2006 & GW-762 & $\mathrm{EF}$ & 2006 & GW-917 & $\mathrm{BC}$ & 2006 \\
\hline GW-722-10 & $\mathrm{EF}$ & 2006 & GW-763 & $\mathrm{EF}$ & 2006 & GW-918 & $\mathrm{BC}$ & 2006 \\
\hline GW-722-14 & $\mathrm{EF}$ & 2006 & GW-764 & $\mathrm{EF}$ & 2003 & GW-919 & $\mathrm{BC}$ & 2003 \\
\hline GW-722-17 & $\mathrm{EF}$ & 2006 & GW-765 & $\mathrm{EF}$ & 2004 & GW-920 & $\mathrm{BC}$ & 2006 \\
\hline GW-722-20 & $\mathrm{EF}$ & 2006 & GW-769 & $\mathrm{EF}$ & 2006 & GW-921 & $\mathrm{BC}$ & 2006 \\
\hline GW-722-22 & $\mathrm{EF}$ & 2006 & GW-770 & $\mathrm{EF}$ & 2006 & GW-922 & $\mathrm{BC}$ & 2006 \\
\hline GW-722-26 & $\mathrm{EF}$ & 2006 & GW-775 & $\mathrm{EF}$ & 2004 & GW-923 & $\mathrm{BC}$ & 2006 \\
\hline GW-722-30 & $\mathrm{EF}$ & 2006 & GW-776 & $\mathrm{EF}$ & 2008 & GW-924 & $\mathrm{BC}$ & 2006 \\
\hline GW-722-32 & $\mathrm{EF}$ & 2006 & GW-779 & $\mathrm{EF}$ & 2008 & GW-925 & $\mathrm{BC}$ & 2006 \\
\hline GW-722-33 & $\mathrm{EF}$ & 2006 & GW-781 & $\mathrm{EF}$ & 2006 & GW-926 & $\mathrm{BC}$ & 2006 \\
\hline GW-723 & $\mathrm{BC}$ & 2005 & GW-782 & $\mathrm{EF}$ & 2006 & GW-927 & $\mathrm{BC}$ & 2006 \\
\hline GW-724 & $\mathrm{BC}$ & 2006 & GW-783 & $\mathrm{EF}$ & 2006 & GW-954-1 & $\mathrm{EF}$ & 2006 \\
\hline GW-725 & $\mathrm{BC}$ & 2006 & GW-786 & $\mathrm{EF}$ & 2003 & GW-954-2 & $\mathrm{EF}$ & 2006 \\
\hline GW-731 & CR & 2006 & GW-787 & $\mathrm{EF}$ & 2003 & GW-954-3 & $\mathrm{EF}$ & 2006 \\
\hline GW-732 & CR & 2006 & GW-791 & $\mathrm{EF}$ & 2006 & GW-956-1 & $\mathrm{EF}$ & 2006 \\
\hline GW-733 & $\mathrm{EF}$ & 2006 & GW-792 & $\mathrm{EF}$ & 2006 & GW-956-2 & $\mathrm{EF}$ & 2006 \\
\hline GW-735 & $\mathrm{EF}$ & 2005 & GW-795 & $\mathrm{BC}$ & 2004 & GW-956-3 & $\mathrm{EF}$ & 2006 \\
\hline GW-736 & $\mathrm{BC}$ & 2005 & GW-796 & CR & 2006 & GW-956-4 & $\mathrm{EF}$ & 2006 \\
\hline GW-737 & $\mathrm{BC}$ & 2005 & GW-797 & CR & 2006 & GW-959 & $\mathrm{EF}$ & 2006 \\
\hline GW-738 & $\mathrm{BC}$ & 2006 & GW-798 & CR & 2006 & GW-960 & $\mathrm{EF}$ & 2008 \\
\hline GW-739 & $\mathrm{BC}$ & 2005 & GW-799 & CR & 2006 & & & \\
\hline
\end{tabular}

Notes:

$$
\begin{aligned}
\mathrm{BC} & =\text { Bear Creek Hydrogeologic Regime } \\
\mathrm{CR} & =\text { Chestnut Ridge Hydrogeologic Regime } \\
\mathrm{EF} & =\text { Upper East Fork Poplar Creek Hydrogeologic Regime }
\end{aligned}
$$


Table B.4. Index of sampling stations included in Volume 5 of the Y-12 GWPP Compendium

\begin{tabular}{|c|c|c|c|c|c|}
\hline Sampling Station & Regime & $\begin{array}{c}\text { Revision } \\
\text { Year }\end{array}$ & Sampling Station & Regime & $\begin{array}{c}\text { Revision } \\
\text { Year }\end{array}$ \\
\hline 200A6 & $\mathrm{EF}$ & 2006 & NT-04 & BC & 2006 \\
\hline $9201-1 \mathrm{~K}-22 \mathrm{SU}$ & $\mathrm{EF}$ & 2004 & NT-07 & $\mathrm{BC}$ & 2006 \\
\hline 9201-3C-4SP & $\mathrm{EF}$ & 2004 & NT-08 & $\mathrm{BC}$ & 2006 \\
\hline BCK-00.63 & $\mathrm{BC}$ & 2005 & NT-8-E & $\mathrm{BC}$ & 2003 \\
\hline BCK-03.30 & $\mathrm{BC}$ & 2006 & NT-8-W & $\mathrm{BC}$ & 2003 \\
\hline BCK-04.55 & $\mathrm{BC}$ & 2006 & OF 51 & $\mathrm{EF}$ & 2006 \\
\hline BCK-07.87 & BC & 2006 & S07 & BC & 2006 \\
\hline BCK-09.20 & BC & 2006 & S17 & CR & 2006 \\
\hline BCK-09.40 & $\mathrm{BC}$ & 2003 & SCR1.25SP & CR & 2006 \\
\hline BCK-09.47 & $\mathrm{BC}$ & 2006 & SCR1.5SW & CR & 2006 \\
\hline BCK-11.54 & BC & 2006 & SCR2.1SP & CR & 2006 \\
\hline BCK-11.84 & $\mathrm{BC}$ & 2006 & SCR2.2SP & CR & 2006 \\
\hline BCK-11.97 & $\mathrm{BC}$ & 2003 & SCR3.5SP & CR & 2006 \\
\hline BCK-12.34 & $\mathrm{BC}$ & 2006 & SCR3.5SW & CR & 2006 \\
\hline BCK-12.47 & $\mathrm{BC}$ & 2006 & SCR4.3SP & $\mathrm{CR}$ & 2006 \\
\hline EMW-VWEIR & $\mathrm{BC}$ & 2006 & SCR7.1SP & UV & 2006 \\
\hline EMW-VWUNDER & BC & 2006 & SCR7.8SP & UV & 2006 \\
\hline EMWNT-03A & $\mathrm{BC}$ & 2006 & SP-17 & $\mathrm{EF}$ & 2006 \\
\hline EMWNT-05 & $\mathrm{BC}$ & 2006 & SPR14.0SP & $\mathrm{EF}$ & 2004 \\
\hline ET-4 & $\mathrm{BC}$ & 2003 & SS-1 & $\mathrm{BC}$ & 2006 \\
\hline GHK2.51ESW & NPR & 2005 & SS-4 & $\mathrm{BC}$ & 2006 \\
\hline GHK2.51WSW & NPR & 2006 & SS-5 & $\mathrm{BC}$ & 2006 \\
\hline MCK 2.0 & CR & 2006 & SS-6 & $\mathrm{BC}$ & 2006 \\
\hline MCK 2.05 & CR & 2006 & SS-6.6 & $\mathrm{BC}$ & 2006 \\
\hline NPR07.0SW & NPR & 2006 & SS-7 & $\mathrm{BC}$ & 2006 \\
\hline NPR12.0SW & NPR & 2006 & SS-8 & $\mathrm{BC}$ & 2006 \\
\hline NPR23.0SW & NPR & 2006 & STATION 8 & $\mathrm{EF}$ & 2006 \\
\hline NT-01 & $\mathrm{BC}$ & 2006 & STATION 17 & $\mathrm{EF}$ & 2006 \\
\hline NT-03 & BC & 2006 & UNC-SW1 & CR & 2008 \\
\hline
\end{tabular}

Notes:

$$
\begin{aligned}
\mathrm{BC} & =\text { Bear Creek Hydrogeologic Regime } \\
\mathrm{CR} & =\text { Chestnut Ridge Hydrogeologic Regime } \\
\mathrm{EF} & =\text { Upper East Fork Poplar Creek Hydrogeologic Regime } \\
\mathrm{NPR} & =\text { North of Pine Ridge } \\
\text { UV } & =\text { Union Valley (East of the EF Regime) }
\end{aligned}
$$




\section{DISTRIBUTION}

\section{U.S. DEPARTMENT OF ENERGY}

J. P. Donnelly, DOE-NNSA ${ }^{2}$

TENNESSEE DEPARTMENT OF

ENVIRONMENT AND CONSERVATION

DOE-ORR OVERSIGHT DIVISION

D. Gilmore ${ }^{1}$

B\&W Y-12, L.L.C. ENVIRONMENTAL COMPLIANCE DEPARTMENT

S. M. Field ${ }^{2}$

C. C. Hill ${ }^{2}$

S. L. Jollay ${ }^{2}$

S. B. Jones

S. E. McNamara ${ }^{2}$

L. O. Vaughan ${ }^{2}$
BECHTEL JACOBS COMPANY LLC

L. M. Sims ${ }^{1}$

R. H. Ketelle ${ }^{1}$

File - EMEF-DMC ${ }^{1}$

SCIENCE APPLICATIONS

INTERNATIONAL CORPORATION

W. K. Jago ${ }^{1}$

UT-BATTELLE, LLC

D. B. Watson ${ }^{1}$

ELVADO ENVIRONMENTAL LLC

T. R. Harrison

J. R. Walker

Y-12 Central Files ${ }^{1}$

9114DMC-01971865.6551-RC ${ }^{2}$

Y-12 Records Services (OSTI) ${ }^{2}$

YDCC - RC ${ }^{1}$

$\begin{array}{lll}\text { Notes: } & 1 & \text { Receives Volume 1, CD includes PDF file of Volumes 2, 3, 4, and } 5 \\ & 2 & \text { Receives PDF file of entire document }\end{array}$ 